\title{
Toward Effective Human Sigma Implementation in the Tourism and Hotel Industry: A Proposed Framework
}

Azza Maher Mahmoud Abou Kamar

Faculty of Tourism and Hotels, University of Sadat City

\section{Abstract}

In today's highly competitive environment, employee-customer engagement has emerged as a key motive of business success. High levels of employee-customer engagement can boost customer loyalty and achieve meaningful operational and financial improvements. A recent innovative research-based approach on the management of employee-customer engagement has actualized a relatively new approach titled: Human Sigma. This new approach focuses on reducing and improving variability in the employee-customer engagement levels in order to improve the quality of the employee-customer encounter. Given, therefore, that this new approach can positively impact the tourism and hotel organizations in their quest to improve service quality, this study presents the concept of Human Sigma as a recognizable and accepted business improvement approach and proposes a framework for its effective application in the tourism and hotel industry in Egypt. The overall goal of this present study is to propose a framework for effective Human Sigma implementation in the tourism and hotel industry in Egypt. The data of the study has been collected through questionnaires directed to the managers of five-star chain hotels and travel agencies (class A) in Egypt. The findings revealed that the vast majority of tourism and hotel organizations in Egypt are aware of the concept of Human Sigma as a business improvement approach. However, a marginal proportion of these organizations are applying formal system for measuring and managing the employee-customer engagement. Practically, the study proposed a framework for effective Human Sigma implementation. More importantly, the findings of this study have several managerial implications which offer the opportunities for further research in the future.

Keywords: Human Sigma, employee-customer engagement, tourism and hotel industry, Egypt.

\section{Introduction}

Quality relationships are essential in the tourism and hotel industry, since they provide services with tangibility. In this context, employees are key part for the effective delivery of quality services, since the service cannot be provided without their participation (Baum, 2007; Montasser and Al Manhawy, 2013). In the meantime, there is a new pattern of customer in the industry who is more aware, more quality conscious, and more sophisticated than before (Pirnar et al., 2010). Hence, in such a very important industry, implementing quality management initiatives is crucial to maintaining customer satisfaction and loyalty (Gupta and Zeithaml, 2006; Mercy and Taiye, 2015).

Furthermore, in the developing countries with large population, such as Egypt, it has become more important to focus on quality management initiatives in the tourism and hotel sector. This sector is considered one of the driving forces of the Egyptian economy. Tourism is currently representing $11.3 \%$ of the country's GDP, $40 \%$ of Egypt's total noncommodity exports, and $19.3 \%$ of Egypt's foreign currency revenues (Egypt State Information Service, 2016). However, the tourism and hotel sector in Egypt is challenged by the sudden and rapid changes occurring in the surrounding internal environment (United Nations Environment Program (UNEP) and World Tourism Organization (WTO), 2005). Therefore, the firms in this sector need to improve their competitiveness with regard to customer satisfaction, customer loyalty, employee satisfaction, employee loyalty, and the quality management initiatives.(Mercy and Taiye, 2015; Simon and Gomez, 2005) Consequently, a number of tourism and hotel firms are concerned with the transactional 
behavior of their customers (purchase frequency, cross-selling, usage level, rate of customer complaints, etc.) since it can affect their sales volumes and revenues instantly and on the long-term (Devie et al., 2011; Yee et al., 2008).

Obviously, the competitive environment nowadays supports another approach to manage the company-customer relationship that controls non-transactional perspectives (word-ofmouth, blogging or referrals, and co-creation amongst others) (Fleming et al., 2005). This can equivocally influence the outcomes of the organization, regardless of the fact that these are not enrolled with brief impact. Consequently, many firms within the tourism and hotel sector have paid more attention to the adoption of quality improvement methodologies in the area of consumer behavior relationship marketing in order to retain their customers for longer runs. The main point here is that these methodologies incorporate the utilization of a broad scope of tools, methods, and tactics that endeavor to manage customer expectations (Bramulya, 2016; Kumar and Antony, 2008; Sutton, 2014a). One of these methodologies is Human Sigma; it is a generally new approach emerged particularly for the service industry. This new approach addresses the issues related to the human frameworks of business to achieve development in engaging the customers of the organization on the emotion level (Sutton, 2014b; Sutton 2015). Human Sigma leads to finding out serious connections between employee and customer. If firms are concerned with their customers only, they may succeed on short term basis. Therefore, they need also to pay attention to their employees in order to sustain success (Fleming and Asplund, 2007). To conclude, Human Sigma focuses on both employee and customer satisfaction at the same level through measuring and managing employee-customer engagement. This helps organizations attract customers and employees and guarantee their loyalty (Sutton, 2014a).

The results of a broad literature review on Human Sigma concept revealed that there is limited research being conducted on the implementation of that concept in the service context (Fleming and Asplund, 2007). It is further observed that the literature also lacks a rigorous research approach in discussion of the implementation issues involving the service industry in general and the tourism and hotel sector in particular. This lack of academic rigor and theory development of Human Sigma implementation is also observed by various researchers (Fleming and Asplund, 2007, Ford et al., 2012). Since this gap is identified, more research on the employee-customer interaction, or more succinctly employee-customer engagement, is required to investigate the philosophy of the Human Sigma concept, which is rather a new concept, and to find out how it can be implemented to improve employees' performance in the tourism and hotel industry in Egypt. Consequently, the aim of this study is to present the concept of Human Sigma as a recognizable and accepted business improvement approach and proposes a framework for its effective application in the tourism and hotel industry in Egypt. With this aim in mind, this study attempts to:

1. Examine the current status of adoption and continued use of business improvement initiatives in the tourism and hotel organizations in Egypt.

2. Asses the levels of awareness and application of Human Sigma in the tourism and hotel organizations in Egypt.

3. Measure the levels of employees-customers engagement using Human Sigma formula.

4. Identify the potential obstacles that hinder the full adoption of Human Sigma principles in the tourism and hotel organizations in Egypt. 


\section{Review of related literature}

\section{Service quality management models}

Basic quality management tools appeared for the first time in the second half of the 20th century. From that point forward, quality management hypothesis has been further created and supported and new models, tools, and approaches have been created, implemented, and analyzed (Pabedinskaite and Vitkauskas, 2011). In addition, the terms quality tools, techniques, and approaches have been used to refer to practical methods and skills used with specific tasks to facilitate change and support business improvement (Sutton, 2014a). Tourism and hotel organizations have endeavored to gain further sustainable competitive advantage by constantly focusing on investing quite heavily in a body of continuous service quality improvement initiatives. For example, some of the common on going service quality improvement initiatives include: Total Quality Management (Dale and McQuater, 1998; Zairi, 2002), ISO 9000 (Nield and Kozak, 1999), Balanced Scorecard (Niven, 2005), and Six-Sigma (Udayai and Kumar, 2012). Each of these initiatives introduces a variety of tools, techniques, and approaches or a 'toolbox' that makes achieving improvement changes much easier. Actually, many of these tools and techniques are old and have been used in many forms for many years. On the other hand, some of the tools, techniques, and approaches are recent, such as Six-Sigma (Sutton, 2014a).

Broadly, the service quality management models commonly known in academic literature are Total Quality Management (TQM), Quality Management System (QMS), and European Foundation for Quality Management (EFQM) (Pabedinskaite and Vitkauskas, 2011). TQM focuses on continuous improvement activities that include the different levels of employees in order to enhance efficiency and internal (employees) and external (customers) satisfaction. Recent research concerned with TQM has differentiated between two main principles: The (Hard) approach, which uses statistical methods to concentrate on continuous improvement, and the (Soft) approach, which focuses on management commitment, leadership, high-involvement work practices, and strategies for organizational culture change (Hansson and Klefsjö, 2003; Kelemen, 2006; Pabedinskaite and Vitkauskas, 2011). Moreover, ISO 9000 is a series of international meta-standards to ensure quality and operational improvements. These standards guide organizations to identify the trends and tools needed to guarantee that their products and services meet customer's needs and to ensure continuous improvement of quality (Pabedinskaite and Vitkauskas, 2011).

In addition, with regard to the qualitative measures of service quality, the Gronroos's model is based on the concept of service quality that depends on customers' perceptions and expectations (Yarimoglu, 2014). On the other hand, considering the quantitative measures, the Gap Analysis Model, which is known as the SERVQUAL model, is the most common one. This model is criticized by some experts. However, it has been adopted in the service sector, particularly in the tourism and hotel industry, in countries such as America, Australia, and the UK. Also, this model is used by both practitioners and academics (Sutton, 2014a).

Indeed, SERVQUAL have conceptual, operational, and measurement problems. Therefore, alternative models, such as SERVPERF (Cronin and Taylor, 1992), have been developed, but they have not been exposed to extensive trials of SERVQUAL. Same authors have mentioned that customers' expectations cannot remain consistent. They also add that there is not strong theoretical evidence that stands for the relevance of the expectationsperformance gap as the basis upon which service quality is measured. Furthermore, Boulding et al. (1993) said that perception statements, such as SERVPERF, should be used to manage service quality. Finally, Bekhet and Al-Alak (2011) discussed the obstacles facing applying SERVQUAL to all service sectors. However, researchers generally agreed 
on that SERVQUAL measurements are reliable indicators of service quality in general (Khan, 2003).

Certainly, not all tools, techniques, and systems are required by one organization. However, some of them are more commonly used in the tourism and hotel industry, whilst others are used infrequently, such as ISO 9000, Six-Sigma, Human Sigma, and Quality Circles (Sutton, 2014a). The use of a variety of tools, techniques, and approaches is actively encouraged in order to gain as full an evaluation of a service as possible. Thus, organizations implement a mix of subjective and quantitative measures and procedures. They also choose to collect feedback through a combination of techniques (Crick and Spencer, 2001; Kandampully, 2003; Kandampully et al., 2001).

Generally speaking, the tourism and hotel industry faces many challenges with regard to service quality management. Some of these challenges are due to its multiple dimensions. Moreover, serious problems related to developing a comprehensive measurement tool to suit all are created because of the multi-dimensional characteristics of service quality (Sutton, 2014a; Sutton 2015). However, there are many business improvement tools, techniques, and approaches that are available nowadays for tourism and hotel managers to choose from. Some of these tools, techniques, and approaches are simple; on the other hand, others are more complex. Also, each of them has its points of strength and weakness (Dale, 2003; Kandampully, 2003; Sutton, 2014a). Therefore, Dale (2003) has suggested that a selection of tools and techniques should be used in order to enhance, develop, and improve a business.

\section{Managing employee-customer engagement}

In service encounters, according to Sluss and Ashforth (2007), customers' interactions with employees in the workplace have a direct effect on customer satisfaction and sales performance. Interactions with employees in the service context form the cumulative experiences that reflect how the customer feels about the service and its provider. Obviously, employees who do not have sufficient experience or have not received appropriate training to deal with customers fail customers' expectations and cause them to retain unpleasant memories of the service (Jamal and Adelowore , 2008; Sutton , 2014a; Sutton , 2014b; Sutton, 2015). Thus, managing the employee-customer engagement effectively and focusing on the customer's whole experience within the service industry in general, and the tourism and hotel sector in particular, should be paid more attention. Although direct consumption of products or services forms a great part of the value delivered to customers, customer satisfaction is not limited to direct benefits, but it also includes non-product benefits. In the tourism and hotel industry, the heart of a service is the person-to-person interaction between the service provider and the guest (Crick and Spencer, 2001; Ford et al., 2012; Sutton, 2015).

According to Sutton (2014b) the service encounter is increasingly recognized as a dynamic, continuous, and multi-dimensional process of interaction between three main parties: The organization, which sets guidelines and policies through its principles and managerial practices; the provider, or the contact personnel (employee), who enacts the policies of the company; and finally the customer, who seeks to satisfy a range of needs. These three key players are interlinked and together they form both the process and outcome of the service engagement). The service triad shown in Figure (1) shows a triangular reflects the direct and indirect interactive relationships among the three parties. 


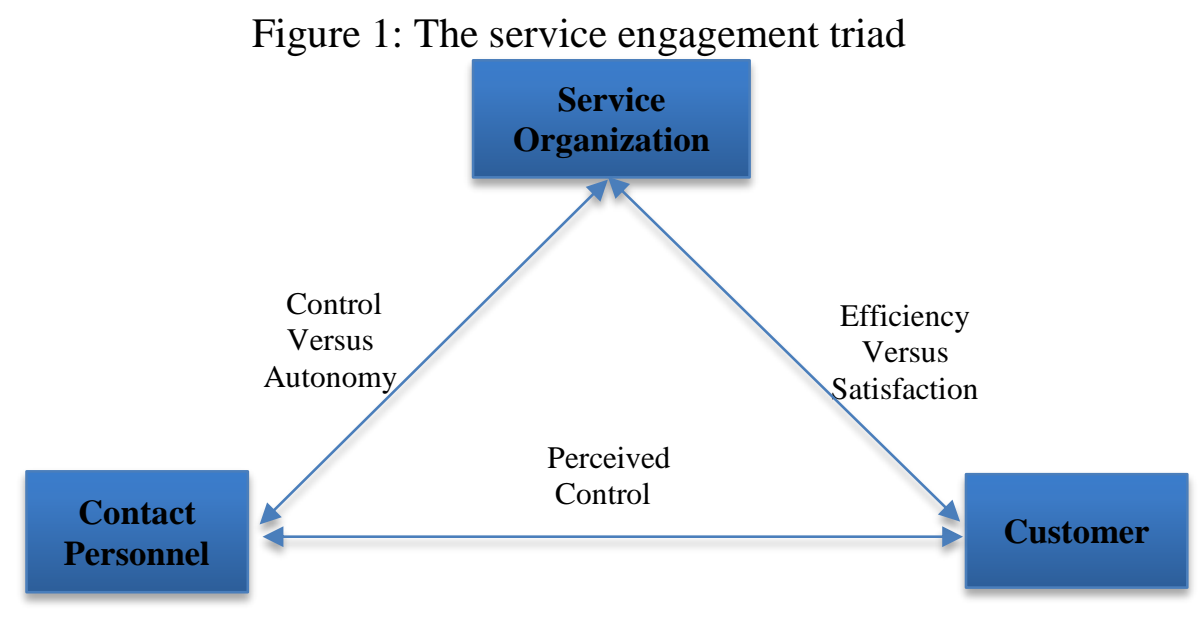

Source: Fitzsimmons and Fitzsimmons (2002)

As cited by Sutton (2014b), engagement is defined as an emotional construct. Thus, the emotional side of the human behavior should be recognized within the process of measuring and managing the employee-customer encounter. However, Maslach et al. (2001) defined work engagement as a permanent, positive, and effective motivational state of fulfillment. Work engagement creates mutual interest among practitioners and academics since it has been proved that there is a positive relationship between work engagement and many relevant firm outcomes (Barnes et al., 2014).

Through evidence of research, customer engagement has been viewed from different prospects. According to Brodie et al. (2013) customer engagement can be presented as a psychological state depicted by an intensification level that plays a pivotal role in the relational business-to- customer exchange between organizations and their customers. Additionally, other traditional relational concepts can act as predecessors and/or results in the customer engagement processes (Brodie et al., 2013; Vivek et al., 2012; Patrson et al., 2006). Accordingly, customer engagement can be defined as "a multidimensional concept comprising cognitive, emotional, and/or behavioral dimensions" (Brodie et al., 2013). Whereas Fernandes and Esteves (2016) provided another perspective of customer engagement which infers a more profound relationally based level and, subsequently, has an essential spot in adding to the comprehension of customer outcomes, namely loyaltyrelated outcomes. Customers' emotional attachment combined with attitudinal loyalty is expected to increase customer retention, frequency of purchase, total spending and, thus, the financial performance at the individual, the work unit, and the enterprise level (Fleming and Asplund, 2007).

Correspondingly, theorists have classified customer engagement into two concepts: Unidimensional and multidimensional. For the unidimensional conceptualization, customer engagement depends mainly on the behavioral aspects. On the other side, multidimensional conceptualization depicts client engagement as involving a few submeasurements including subjective, passionate, and behavioral (Puriwat and Tripopsakul, 2014).

In addition, more attention has been paid to the new concept of employee engagement by the end of the $20^{\text {th }}$ century. Kahn in 1990 was the first to talk about employee engagement (Slåtten and Mehmetoglu, 2011), defining it as "simultaneous employment and expression of a person's preferred self in task behaviors that promote connections to work and to others, personal presence (physical, cognitive, and emotional), and active full role performances". Thence, for Kahn, employee engagement is best defined as a multidimensional, motivational concept that reflects the synchronous articulation of an 
employee's physical, enthusiastic, and psychological energy at work (Eldor and VigodaGadot, 2016).

Rothbard (2001) has proposed that there are two essential components required in employee engagement: Attention and absorption. Attention alludes to the subjective assets, including the focus and mental accentuation that an employee invests in work. Absorption alludes to the condition of being totally focused and highly engrossed at work, being profoundly fascinated and not effectively occupied by redirections. Rich et al. (2010) have widened Rothbard's measure of engagement and proposed a multidimensional viewpoint of employee engagement which incorporates three subcomponents: Physical, passionate, and psychological. Moreover, employee engagement is described by other scholastics as a dynamic, fulfilling, and work related approach that includes effective engagement as part of the organization and self-expression (Brodie et al., 2013; Bakker et al., 2011; Eldor and Vigoda-Gadot, 2016; Rothbard and Patil, 2010).

In general, employees and customers can be classified into three engagement categories: Engaged, neutral, and actively disengaged. First, engaged employees are mentally dedicated to their work and the organization (Zweifel, 2010). They are more likely to restore their success after a difficult customer interaction and less likely to damage the customer experience due to any kind of mistreatment, a risk that may result in a high turnover of employees (Brodie et al., 2013; Wang et al., 2011). After experiencing a failure or difficulty, engaged employees are more likely to pursue self-improvement by proactively seeking out opportunities to learn from senior coworkers and leaders. They also report a greater willingness to adapt to change which is an essential trait since companies evolve products and services to better engage customers. As a result, employees will continue to go above and beyond to deliver the intended customer experience despite setbacks and changes (Brodie et al., 2013; Patrson et al., 2006; Welch and Welch, 2006; Vivek et al., 2012).

Positively, engaged employees achieve more efficiency and productivity, better security and participation records, and higher levels of retention (Wagner and Harter, 2006). Additionally, they are more successful at attracting and retaining the customers they serve. Organizations that make employee engagement and customer engagement their priority have a positive movement in the general business achievement (Zweifel, 2010). Engaged employees are the most beneficial and effective specialists of an organization. They feel associated inwardly, socially, and even profoundly to the central goal, vision, and reason of the organization (Brodie et al., 2013). They are also more interested in finding creative solutions to handle customers' issues (Fleming and Asplund, 2007). One factor that impacts client engagement is employees' readiness to proceed to learn and develop in their jobs, keeping in mind the end goal to have the capacity to meet customers' evolving needs (Zweifel, 2010).

On the other hand, disengaged employees are in a neutral position; they are not very useful to the organization and they do not have a clear optimistic or pessimistic view towards the organization. They are described as being sleepwalkers during their workday. They spend time at office, but they are not exerting effort or having passion towards their work (Dale, 2003; Zweifel, 2010). In addition, these employees underestimate the achievements of the other engaged coworkers (Dale, 2003).

With the end goal to accomplish and maintain development, organizations need to expand consumer loyalty, as well as the bottom-line performance. One approach to accomplish this is to have a profoundly engaged workforce of proficient and gifted employees (Schroder, 2002; Tyler, 2005; Bassi and McMurrer, 2007). In any business, one of the keys to achieve sustainable competitiveness is to offer customers more than what they anticipate (Coulter, 2002). Instructing employees to address and properly manage customer issues is 
critical if a business needs to keep customers. Since employees are humans, not each employee-customer encounter brings about a satisfied customer; customer interactions in this way turn out to be progressively imperative. Discovering approaches to increase the engagement rates of employees and customers lead to amazing results. Increased retention, expanded efficiency, expanded customer devotion, and expanded benefits are all motivations to explore engagement (Coffman and Michelman, 2004; Rath, 2004; Zweifel, 2010).

\section{Human Sigma: definition and main features}

Human Sigma is a recent approach developed particularly to improve the quality of the human aspects within service contexts (Sutton, 2014a). The Human Sigma model, initially created by Fleming and Asplund (2007), is an approach to gauge and deal with the human frameworks of business. It has been created as a reaction to the absence of the viability of the Six-Sigma technique in measuring and managing the human aspects. Since, the SixSigma methodology has changed the face of manufacturing quality. Six-Sigma is a metric methodology applied to enhance quality and lessen mistakes in business forms (Antony, 2005). It concentrates on diminishing variety in quality by lessening blunders in products and procedures to underneath 3.4 imperfections for every million opportunities (Raghunath and Jayathirtha, 2013). Presently, Human Sigma is ready to do likewise for sales and services. The relationships between Human Sigma and Six-Sigma concentrate for the most part on decreasing variability and enhancing hierarchical execution to drive profitability and development. Unlike Six-Sigma, Human Sigma focuses on the human elements of organizational performance to drive productivity and development. The bundle of quality instruments, the thoughtfulness regarding zero defects, and the center of the problem solving methods of activities are the Six-Sigma approaches, which are frequently less appropriate for the tourism and hotel sector. When contrasted with Human Sigma, the employee and customer engagement process applying Six-Sigma is more arranged and appropriate to the tourism and hotel sector (Adam, 2003; Antony, 2005; Antony et al., 2007; Sutton, 2014a). The similarities and contrasts between Six-Sigma and Human Sigma are summarized in Table (1).

Table 1: A comparison between Six-Sigma and Human Sigma

\begin{tabular}{|l|l|}
\hline \multicolumn{1}{|c|}{ Six-Sigma } & \multicolumn{1}{|c|}{ Human Sigma } \\
\hline Rigid and relevant data and fact-based & $\begin{array}{l}\text { Measurement and management of the levels of } \\
\text { employee-customer engagement }\end{array}$ \\
\hline $\begin{array}{l}\text { Systematic and methodological } \\
\text { approach }\end{array}$ & Aggregate approach \\
\hline Pursuit of zero defects & $\begin{array}{l}\text { Diminish the levels of actively disengaged } \\
\text { employees and customers }\end{array}$ \\
\hline Prevention of imperfections/defects & $\begin{array}{l}\text { Concentrate on the human performance of } \\
\text { hierarchical execution to drive financial benefits } \\
\text { and development }\end{array}$ \\
\hline Improve financial benefits & Financial benefits and development \\
\hline $\begin{array}{l}\text { Senior management involvement is } \\
\text { required }\end{array}$ & $\begin{array}{l}\text { The employee-customer encounter is measured } \\
\text { locally to avoid variations in quality at the } \\
\text { individual level }\end{array}$ \\
\hline $\begin{array}{l}\text { Facilities and ongoing training are } \\
\text { required }\end{array}$ & $\begin{array}{l}\text { Metrics are used to measure employee-customer } \\
\text { transactional and non-transactional behaviors }\end{array}$ \\
\hline $\begin{array}{l}\text { Quantitative estimation of quality, } \\
\text { immeasurable scope of devices and }\end{array}$ & $\begin{array}{l}\text { Evaluated and outlined in a single performance } \\
\text { metric (measures the levels of employee- }\end{array}$ \\
\hline
\end{tabular}




\begin{tabular}{|l|l|}
\hline $\begin{array}{l}\text { procedures with a scope of } \\
\text { measurements }\end{array}$ & customer engagement) \\
\hline $\begin{array}{l}\text { Initially intended for the manufacturing } \\
\text { segment }\end{array}$ & $\begin{array}{l}\text { Targeted service firms with a high level of } \\
\text { direct customer contact (as in the tourism and } \\
\text { hotel industry) }\end{array}$ \\
\hline
\end{tabular}

Source: Sutton, (2014).

Human Sigma was defined by Fleming and Asplund (2007) as "a disciplined approach to measure, manage and improve the performance of customers and employees to drive financial performance". The authors additionally expressed that firms that have accomplished a perfect level of engagement have overcome their rivals by $26 \%$ in gross edge, and $85 \%$ in deals advancement, in light of the fact that engaged customers spend progressively and return more often. Human Sigma is thought to interface the way of the employee-customer engagement, weaving together a solid system for studying each involvement and a reliable strategy for upgrading future engagement. In this context, Human Sigma focuses on diminishing vacillation through enhancing the human performance. Human Sigma offers a comprehensive approach to deal with employeecustomer interaction which leads to enhanced development and profitability (Sutton, 2014a).

The Human Sigma metric measures the level of human interaction between employees and customers at the level of the local unit. In order to realize business achievement, the 'vital signs' of an organization, such as employee and customer engagement and financial outcomes, should be tracked (Fleming and Asplund, 2007). The same authors also state that managing and measuring the employee-customer encounter are very important. From the perspective of the local unit performance, customer and employee engagement helps to improve and accelerate financial performance process generally (Sutton, 2014b). Organizations with high/excellent Human Sigma performance are where the majority of their local units or teams are optimized in the top 50\% on both employee and customer engagement (Fleming and Asplund, 2007). The performance of the organizations, or so called business units, can be summarized as follows:

1. Organizations or local units at (Human Sigma 1) and (Human Sigma 2) perform less than impressive on employee or customer engagement metrics, and they need serious improvement.

2. Organizations or local units at (Human Sigma 3) are also frequently not balanced, focusing highly on one important sign, yet not considering the other.

3. Organizations at (Human Sigma 4) are classified as emerging successful performers. They have imposed equality in the imperative indications of the employee-customer experience, yet there are still many increases to be made to reinforce these metrics.

4. Organizations at (Human Sigma 5) and (Human Sigma 6) are identified as extraordinary performers.

5. generally speaking, organizations in Human Sigma (4, 5, and 6) are 3.4 times more effective financially than Human Sigma (1, 2, and 3) (Fleming and Asplund, 2007).

Furthermore, the same authors mentioned that there are two ways for organizations to achieve Human Sigma 5 and Human Sigma 6. The first way is periodic interferences or transactions which incorporates activities such as critical thinking activities that help organizations discover approaches to do what they already do, yet better, e.g., activity arranging, conceptualizing, process enhancements, and Six-Sigma activities. Furthermore, business employees and supervisors meet routinely to talk about their scores and pick a few things to concentrate on managing or developing. The second way is structural or transformational interventions where the main attention is paid to how the business is 
managed, how leadership is shaped, and how decisions are made. Structural interventions include employees' selection, directors' promoting, employees' appraisal, progression planning, and employees' development (Lovelock and Wirtz, 2011). Therefore, transactional and transformational activities are essential for organizational performance improvement (Sutton, 2014a).

Gallup, the worldwide research-based consultancy specialized in employee and customer management, has built up a quantitative component to gauge employee and customer encounter. Taking into account scoring sets of particular questions asked to both employees and customers, the Human Sigma metric of an organization is a count of relative employee and customer engagement scores. Gallup has recognized twelve key questions that serve as a marker of the degree of employee engagement in an organization. This instrument asks employees to answer twelve questions to find out whether they fall into the engaged, non-engaged, or actively disengaged categories. This instrument also examines whether employees have the materials they need to execute their job and the clarity of their standards. It also explores whether their supervisors appreciate them, whether their voices are considered, and whether they are given opportunities to learn and develop. The two overviews together constitute the premise for Human Sigma (Michelli, 2008).

\section{Application and alignment in the tourism and hotel contexts}

Tourism and hotel industry is characterized by frequent, complex, and often inimitable engagement between employees and customers. Many organizations in the industry have a customer and employee measurement program in place as an essential management process. Frequently, these activities are claimed by functional areas of the business that work in confinement, e.g., employee measurement programs are often managed by the human resources department. Customer measurement programs are usually managed by the marketing, operations, or quality departments. Only rarely that functional areas communicate (Fleming and Asplund, 2007; Lovelock and Wirtz, 2011). This absence of arrangement and co-appointment restrains an organization examination on its customers and employees and discourages their capacity to utilize this data they gather viably (Sutton, 2014b). Fleming and Asplund (2007) have recorded that limitless varieties in customer and employee engagement from organization to organization, location to location, and team to team exist within an organization. This considerable fluctuation in customer and employee engagement constitutes a noteworthy risk to the supportability of the organization and draws down the monetary and operational performance. The same authors also proposed that the best way to deal with that changeability is to give performance input at the local business unit where employees invest the vast majority of their energy and where customer experience is made.

In addition, the Human Sigma theory goes a step further and argues that the emotional aspect of customer commitment (i.e. customer's emotional attachment) is very important. There are four dimensions of emotional attachment that can be placed in a hierarchical order as follows: Confidence (consistency between promises and delivery), Integrity (fairness of solutions), Pride (positive association and identification with the company), and Passion (internalization of self-fulfilling prophecy that the company is perfect for the customer) (Gemmel and Verleye, 2010). According to the hierarchy, it is difficult to be proud and passionate about a company without having a feeling of confidence and integrity. Customers' emotional attachment combined with attitudinal loyalty is expected to increase customer retention, frequency of use, total revenue, total spending, and, thus, the business performance at the individual, the work unit, and the enterprise level (Fleming and Asplund, 2007; Gemmel and Verleye, 2010). The Human Sigma management model 
is designed to suit any organization. However, it is specifically intended to organizations that have a high level of direct customer interaction, such as in the tourism and hotel sector. Despite the fact that this model might be implemented in different ways, there are five principles behind its fundamental rationality concerned with the employee-customer encounter. The five new principles of Human Sigma Management are abridged in Table (2).

Table 2: The new principles of Human Sigma management

\begin{tabular}{|l|l|}
\hline Rule 1 & $\begin{array}{l}\text { The employee and customer experiences cannot be managed and measured } \\
\text { as separate entities. }\end{array}$ \\
\hline Rule 2 & Emotion frames the employee-customer encounter. \\
\hline Rule 3 & $\begin{array}{l}\text { The employee-customer encounter must be measured and managed at the } \\
\text { local levels. }\end{array}$ \\
\hline Rule 4 & $\begin{array}{l}\text { The effectiveness of the employee-customer encounter should be quantified } \\
\text { and summarized through the Human Sigma metric that is related to financial } \\
\text { performance. }\end{array}$ \\
\hline Rule 5 & $\begin{array}{l}\text { Improvement in local Human Sigma performance requires deliberate and } \\
\text { active intervention through attention to a combination of transactional and } \\
\text { transformational intervention activities. }\end{array}$ \\
\hline
\end{tabular}

Source: Fleming and Asplund (2007).

\section{Methodology}

Based on the research objectives, an integrated methodology of both quantitative and qualitative approaches have been employed to collect the relevant information. To supplement the qualitative approach, data have been collected from related literature to give more insight concerning the topic being investigated. In addition, quantitative data have been collected through a self-administered online survey in order to obtain conclusive descriptive data from five-star chain hotels and travel agencies in Egypt. Consistent with prior research, (Fleming and Asplund, 2007; Michelli, 2008; Bowden, 2009; Sutton, 2014a) various attributes validated in previous research have been adopted. A multipleitem method has been adopted to structure the questionnaire. Most of the items are rated on a five-point Likert scale ranging from (1) strongly disagree to (5) strongly agree. The questionnaire is divided into three parts: The first part of the survey asks the respondents to identify the profiles of their organizations, including the type of business, the duration of organization operation, the organization paid-up capital, the approximate number of employees in the organization, and the quality initiatives/programs being implemented by the organization. In the second part of the survey, the respondents are requested to identify whether the organization has a formal employee-customer engagement measurement program in place. This section is designed to identify the respondents' perspectives regarding measurement and management of interactions between customers and employees (the main principle of Human Sigma) in the organization. Moreover, this section asks the respondents to identify employee engagement level and organization priorities related to customer engagement. In the third part of the survey, the respondents are asked to identify the potential obstacles which they might consider while implementing Human Sigma.

\section{Population and sampling techniques}

The population outline for the present study incorporates all five-star chain hotels and travel agencies (class A) in Egypt throughout 2015/2016. Five-star chain hotels and travel agencies (class A) have been selected for this study because they have the advantages of 
accumulated experiences, the availability of professional operating systems, continuous training programs, and formal programs for measuring employee and customer satisfaction. The population frame included (113) five-star chain hotels, based on the complete census technique, and (347) travel agencies out of 1277 travel agencies in Great Cairo (class A), based on the convenience sample technique since the population is variable and difficult to be characterize. The names, addresses, and e-mails of the population have been acquired from the Directory of Tourism Companies produced by the Egyptian Cabinet Information and Decision Support Center (IDSC), and also from the Egyptian Hotel Guide (35 ${ }^{\text {th }}$ edition, 2015) produced by the Egyptian Federation of Tourist Chamber (EFTC). Because of the size of the population and its discrimination in several governorates, the final questionnaire survey has been managed through an online survey development cloud-based site: SurveyMonkey. This technique proves to be the most suitable and economical technique that can be applied in order to collect data. A package, containing an introductory letter explaining the objectives of the study, a brief description of human sigma approach, the survey and how to complete the online survey, was sent by e-mail to the selected companies in April 2016.

\section{Pretesting the questionnaire survey}

In order to ensure that the questionnaire survey developed for this study is precise and accurate, it has been necessary to assess the "appropriateness" of the attributes. Consequently, pilot surveys have been conducted to reclassify and rephrase some attributes of the questionnaire. A total of 20 pilot surveys have been completed with faculty members in tourism and hotel management programs. Based on the feedback received, wording of some items has been slightly altered to match the specific context of this study.

\section{Testing the reliability of the questionnaire}

A reliability test has been applied to measure the internal consistency of the attributes of the questionnaire. The Cronbach alpha factor has been applied to measure the internal consistency of the same group of the questionnaire. In general, reliability coefficients of 0.70 or more are viewed as adequate (Aichouniet al., 2014). The findings demonstrate that the Cronbach's alpha for the entire attributes of the questionnaire, running from 0.7150 to 0.8486 , reflects the internal consistency and reliability of these attributes.

\section{Data analysis methods}

The Statistic Package of the Social Sciences (SPSS v 22.0) was applied in order to analyze the data obtained in this study. Simple frequencies, mean ratings, and standard deviation have been computed to classify the sets and find out whether the sample is homogenous or inconsistent, with regard to all research variables. Spearman correlation coefficient has been used to determine if there is significant relationship between respondents' characteristics and the levels of awareness and application of business improvement initiatives, including Human Sigma principles, in the investigated organizations. The T-test also was utilized to assess whether the means of the two samples (hotels and travel agencies) are statistically different from each other. Furthermore, the human Sigma formula was used to measure the level of the employee-customer engagement in the tourism and hotel organizations in Egypt.

\section{Findings and discussion \\ Response rate}

A total of (321) responses are collected; (12) incomplete responses have been removed, and (309) responses are used for analysis (See Table 3). The respondents represent a group 
of general managers, quality managers, human resources managers, development managers, and/or customer relationship managers of the investigated firms, all of whom have substantial experience and are considered experts in the field of quality management concepts and practices. In addition, this group also corresponds to upper level of management in the organizational structure of their companies.

Table 3: Response rate of the investigated sample

\begin{tabular}{|l|c|c|c|}
\hline Category & $\begin{array}{c}\text { Distributed } \\
\text { questionnaires }\end{array}$ & $\begin{array}{c}\text { Valid } \\
\text { questionnaire }\end{array}$ & $\%$ \\
\hline Five-star hotel chains & 113 & 103 & $91 \%$ \\
\hline Travel agencies & 347 & 206 & $59 \%$ \\
\hline Total & 460 & 309 & $67 \%$ \\
\hline
\end{tabular}

As displayed in Table (3), a total of (103) questionnaire forms are valid out of the total forms collected from the investigated hotel chains with a response rate of $(91 \%)$. Moreover, a total of (206) questionnaire forms are valid from the travel agencies with a response rate of (59\%). Thus, the average response rate is $(67 \%)$. This response rate can be regarded as satisfactory for this kind of surveys (Nulty, 2008).

\section{Profile of the organizations}

In the first part of the questionnaire, there are questions to identify the profiles of the surveyed respondents. Table (4) shows the characteristics of the respondents from five-star chain hotels and travel agencies (class A). Table (4) highlights that the majority of the respondents from five-star chain hotels and travel agencies belong to the senior management category. These insights give more certainty about the results of the current study since the investigated population has ended up being firmly related to the decisionmaking process. It is notable that about $(75 \%)$ of the respondents from five-star chain hotels and $(80 \%)$ of the respondents from travel agencies recognized themselves to be national private companies.

Table 4: Profile of respondents

\begin{tabular}{|l|c|c|c|c|}
\hline \multirow{2}{*}{ Variable } & $\begin{array}{c}\text { Five-star hotel chains } \\
(\mathbf{n = 1 0 3})\end{array}$ & \multicolumn{2}{c|}{$\begin{array}{c}\text { Travel agencies } \\
(\mathbf{n = 2 0 6})\end{array}$} \\
\cline { 2 - 5 } & Freq. & \% & Freq. & \% \\
\hline Position: & 42 & 40.8 & 108 & 52.4 \\
\hline General Manager/Director & 19 & 18.4 & 48 & 23.3 \\
\hline Quality Manager & 25 & 24.3 & 32 & 15.5 \\
\hline Human Resources Manager & 6 & 5.8 & 8 & 3.9 \\
\hline Development Manager & 11 & 10.7 & 6 & 2.9 \\
\hline Customer Relationship Manager & 0 & 0.00 & 4 & 1.9 \\
\hline Others & 77 & 74.7 & 165 & 80.1 \\
\hline Type of the firm: & 12 & 11.7 & 23 & 11.2 \\
\hline National Private Company & 14 & 13.6 & 18 & 8.7 \\
\hline Foreign Ownership & 14 & 13.6 & 6 & 2.9 \\
\hline Joint Venture & 38 & 36.9 & 31 & 15.0 \\
\hline Duration of operation: & 51 & 49.5 & 169 & 82.0 \\
\hline < 10 Years & \multicolumn{5}{|l}{} \\
\hline From 10-20 Years & \multicolumn{5}{|l|}{} \\
\hline > 20 Years & \multicolumn{5}{|l|}{} \\
\hline Annual gross revenue: & \multicolumn{5}{|l|}{} \\
\hline
\end{tabular}


International Journal of Heritage, Tourism and Hospitality Vol. (11), No. (1/2), March, 2017 By: Faculty of Tourism and Hotels, Fayoum University

\begin{tabular}{|l|c|c|c|c|}
\hline $\begin{array}{l}\text { Less than 50 million EGP } \\
\text { From 50 million to less than 100 } \\
\text { million }\end{array}$ & 69 & 67.0 & 21 & 10.2 \\
\hline $\begin{array}{l}\text { More than 100 million EGP } \\
\text { Size of the firm: }\end{array}$ & 34 & 33.0 & 0 & 0.00 \\
\hline$<100$ employees & 0 & 0.00 & 75 & 36.4 \\
\hline From 100 to 300 employees & 43 & 41.7 & 111 & 53.8 \\
\hline$>300$ employees & 60 & 58.3 & 20 & 9.7 \\
\hline
\end{tabular}

The firms participated in the survey have been asked to identify the duration of their operation. More than three-quarters $(82 \%)$ of the travel agencies have operated for more than twenty years. In addition, $(49.5 \%)$ of the five-star hotel chains have operated for more than twenty years. Therefore, it may be inferred that the firms participated in this study have experience, and they are also likely to be fairly well-known brands. The labor power of 60 hotels (58.3\% of the sample) is more than 300 employees, while 43 of them $(41.7 \%$ of the sample) are within the range of 100 to 300 employees. Hotels that employ less than 100 employees have not been found. This is not surprising when considering that generally five-star hotels in Egypt tend to be of a medium to large size. Furthermore, the majority of respondent hotels (67\%) reap between 50 million EGP and 100 million EGP as annual gross revenue. On the other side, the labor power of 111 travel agencies $(53.8 \%$ of the sample) is within the range of 100 to 300 employees, while only 20 of them $(9.7 \%$ of the sample) employ more than 300 employees. Moreover, 185 travel agencies (89.8\%) reap less than 50 million EGP as annual gross revenue, while the minority of these agencies (21 companies, $10.2 \%$ of the sample) generates less than 100 million EGP as annual gross revenue.

\section{Status of business improvement initiatives}

With respect to the implementation of business improvement initiatives, the current study constructed two dummy variables to represent various types of active commitment to quality initiatives in the investigated firms. The first variable indicated whether the firms have implemented any business improvement initiatives along with improvement tools and techniques. The second variable identified the international certificates obtained by the investigated firms. A summary of the values for the level of implementation of business improvement initiatives in both five-star hotel chains and travel agencies are presented in Figure (2).

Figure 2: The business improvement initiatives implemented by the investigated firms

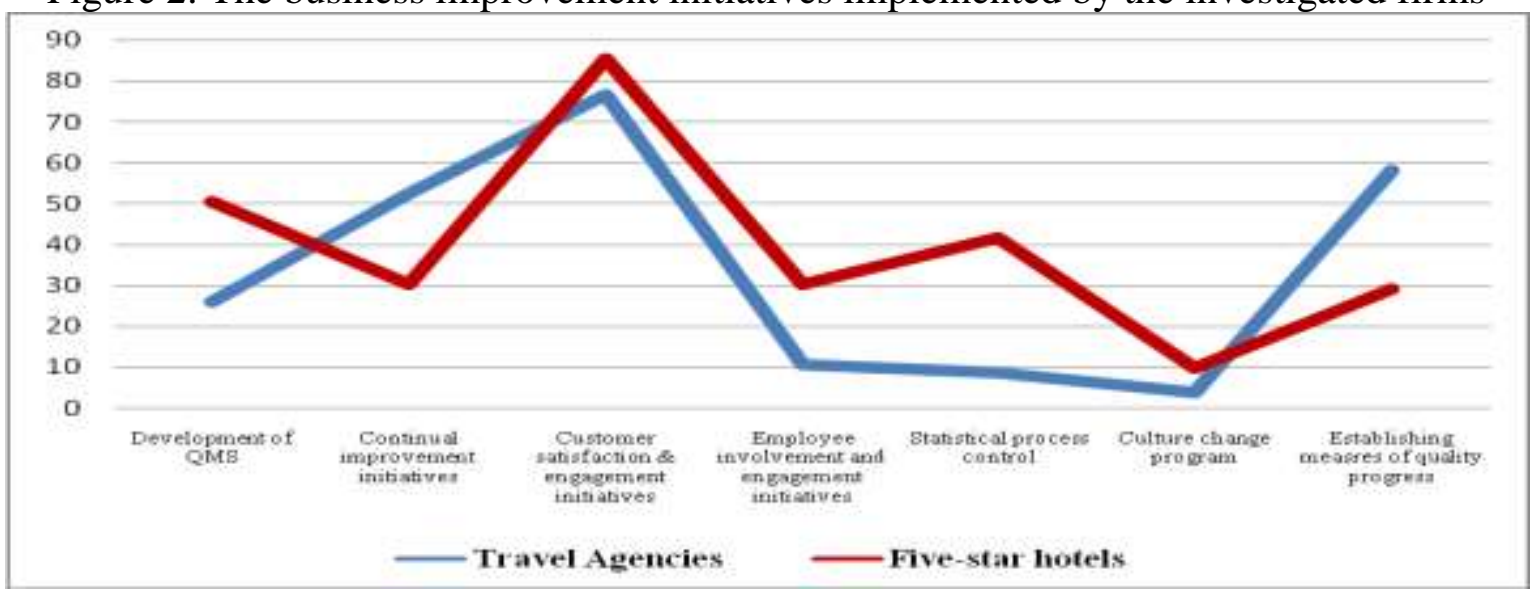


With reference to the five-star hotel chains, results shown in Figure (2) indicate that 52 hotels $(50.5 \%$ of the sample) implement quality management systems. A small number of hotels ( 31 hotels, $30.1 \%$ of the sample) implement continuous improvement initiatives. It can be depicted from Figure (2) that the vast majority of the surveyed hotels $(85.4 \%)$ implement customer satisfaction initiatives. On the other hand, a fewer number of hotels (31 hotels, $30.1 \%$ of the sample) implement employee involvement initiatives. Additionally, it is notable that about (41.7\%) of the respondents apply statistical processes control. In addition, and also according to the results depicted by (Figure 2), the majority of travel agencies (158 companies, $76.7 \%$ of the sample) implement customer satisfaction and engagement initiatives. However, the results indicate that a marginal proportion (i.e. $10.7 \%$ ) of these companies apply employee involvement and engagement initiatives. More than two quarters of them (52.4\% of the sample) use business continuous improvement initiatives, while 54 companies (26.2\% of the sample) use quality management systems. The rest of the companies implement other quality initiatives, such as statistical process control and culture change initiatives, to a lesser extent.

Moreover, a question has been postured to identify the types of international quality certificates gained by the investigated firms. A firm is certified if it possesses the ISO 9001:2008 quality management system, or, alternatively, the TQM, Six-Sigma certificates. Results clearly reveal that more than half of the five-star hotel chains $(58.3 \%)$ have stated that their firms are certified with Total Quality Management (TQM). In addition, it is found that $(41.7 \%)$ of the surveyed hotels have got the ISO 9001:2008 certificate. Only $(14.6 \%)$ of the investigated hotels have been actively involved in Six-Sigma certificates. In addition, the results highlight that Total Quality Management (TQM), with (56.3\%) of the sample and ISO 9001 have been implemented the most in the travel agencies, respectively. Only $(9 \%)$ of the investigated travel agencies have been actively involved in Six-Sigma certificates.

\section{Levels of awareness and application of human Sigma}

One of the main objectives of the present study is to investigate the levels of awareness and application of the Human Sigma principles in the tourism and hotel organizations in Egypt. A five-point Likert scale is adopted to measure respondents' attitudes toward the level of awareness of Human Sigma principles on a scale ranging from (1) No awareness to (5) Excellent awareness. Similarly, a five-point Likert scale is used to evaluate the level of application of the Human Sigma principles on a scale ranging from (1) No use to (5) Extensive use. The results are analyzed in Table (5) and Figure (3).

Table 5: Levels of awareness and application of the Human Sigma principles

\begin{tabular}{|l|c|c|c|c|}
\hline Variable & \multicolumn{2}{|c|}{$\begin{array}{c}\text { Level of } \\
\text { awareness }\end{array}$} & \multicolumn{2}{c|}{$\begin{array}{c}\text { Level of } \\
\text { application }\end{array}$} \\
\cline { 2 - 5 } & Mean & SD & Mean & SD \\
\hline Five-star hotel chains (n=103) & 2.48 & 1.47 & 2.41 & 1.44 \\
\hline $\begin{array}{l}\text { 1. The company is trying to engage their employees and } \\
\text { customers to deeper levels. }\end{array}$ & & & & \\
\hline $\begin{array}{l}\text { 2. Adopting a formal employee-customer engagement } \\
\text { measurement program (Human Sigma) in place. }\end{array}$ & 2.54 & 1.32 & 1.70 & 1.54 \\
\hline $\begin{array}{l}\text { 3. The employee-customer experiences are measured and } \\
\text { managed locally. }\end{array}$ & 2.01 & 1.27 & 2.17 & 1.31 \\
\hline $\begin{array}{l}\text { 4. Engaging customers emotionally is important to gain } \\
\text { their loyalty. }\end{array}$ & 2.41 & 1.44 & 2.27 & 1.42 \\
\hline 5. Employee engagement, at an emotional level, is as & 2.14 & 1.28 & 2.34 & 1.41 \\
\hline
\end{tabular}


crucial to the success of the business as customer engagement.

6. Using judgment and behavior when assessing the employee-customer interaction.

7. Performance metrics are combined with Human Sigma metrics which involve the levels of employee-customer engagement.

8. Improvement strategies are tailored to suit each department's level of engagement.

9. Rewards and recognition of employees are designed to encourage continuous improvement.

10. The company is planning to go beyond achieving customer satisfaction.

Average level

\begin{tabular}{|l|l|l|l|} 
& & & \\
\hline 2.75 & 1.24 & 2.63 & 1.42 \\
\hline 2.10 & 1.25 & 2.07 & 1.30 \\
\hline 2.27 & 1.35 & 2.01 & 1.27 \\
\hline 3.20 & 0.95 & 3.17 & 1.04 \\
\hline 2.30 & 1.39 & 2.18 & 1.42 \\
\hline $\mathbf{2 . 4 2}$ & $\mathbf{1 . 2 9}$ & $\mathbf{2 . 1 2}$ & $\mathbf{1 . 2 0}$ \\
\hline
\end{tabular}

Travel Agencies $(n=206)$

1. The company is trying to engage its employees and customers to deeper levels.

2. Adopting a formal employee-customer engagement measurement program (Human Sigma) in place.

3. The employee-customer experiences are measured and managed locally.

4. Engaging customers emotionally is important to gain their loyalty.

5. Employee engagement, at an emotional level, is as crucial to the success of the business as customer engagement.

6. Using judgment and behavior when assessing the employee-customer interaction.

7. Performance metrics are combined with Human Sigma metrics which involve the levels of employee-customer engagement.

8. Improvement strategies are tailored to suit each department's level of engagement.

9. Rewards and recognition of employees are designed to encourage continuous improvement.

10. The company is planning to go beyond achieving customer satisfaction.

Average level

\begin{tabular}{|l|l|l|l|}
\hline 2.41 & 1.47 & 2.35 & 1.37 \\
\hline 2.21 & 1.54 & 1.25 & 1.40 \\
\hline 2.20 & 1.29 & 2.18 & 1.36 \\
\hline 2.31 & 1.45 & 2.27 & 1.30 \\
\hline 2.55 & 1.43 & 2.47 & 1.45 \\
\hline 2.70 & 1.50 & 2.52 & 1.54 \\
\hline 2.01 & 1.29 & 2.15 & 1.41 \\
\hline 2.34 & 1.37 & 2.27 & 1.24 \\
\hline 2.35 & 1.24 & 2.30 & 1.47 \\
\hline 2.34 & 1.41 & 2.35 & 1.52 \\
\hline $\mathbf{2 . 3 4}$ & $\mathbf{1 . 3 9}$ & $\mathbf{2 . 0 8}$ & $\mathbf{1 . 2 6}$ \\
\hline
\end{tabular}

As shown in Table (5), a notable proportion of the respondents recognized Human Sigma; however, a marginal proportion of the respondents were involved in the application of formal employee-customer engagement measurement program (Human Sigma). Thus, it can be inferred that Human Sigma has not been grasped by the tourism and hotel organizations in Egypt. These results clearly reveal the alarming situation regarding the applicability of formal employee-customer engagement measurement program in the tourism and hotel organizations in Egypt.

The level of awareness and application of Human Sigma principles, are also analyzed in Figure (3). Once more, it is clearly shown that the general propensity of five-star hotel chains and travel agencies investigated in this study is characterized by low application 
rates. As shown in Table (5), the survey provided principles of Human Sigma that respondents might be using or plan to use in one to two years. Out of the principles listed on the instrument, the majority of the hotel respondents chose rewards and recognition of employees are designed to encourage continuous improvement as the most applied principle currently. The least applied principles were the employee-customer experiences are measured and managed locally and performance metrics are combined with Human Sigma metrics.

Within the same context, using judgment and behavior when assessing the employeecustomer interaction was found to be the main principle which is applied in travel agencies in all the investigated companies. Other principles such as engaging employees at an emotional level, engaging the employees and customers to deeper levels, followed respectively the above mentioned principle.

Figure 3: The level of awareness and application of Human Sigma principles

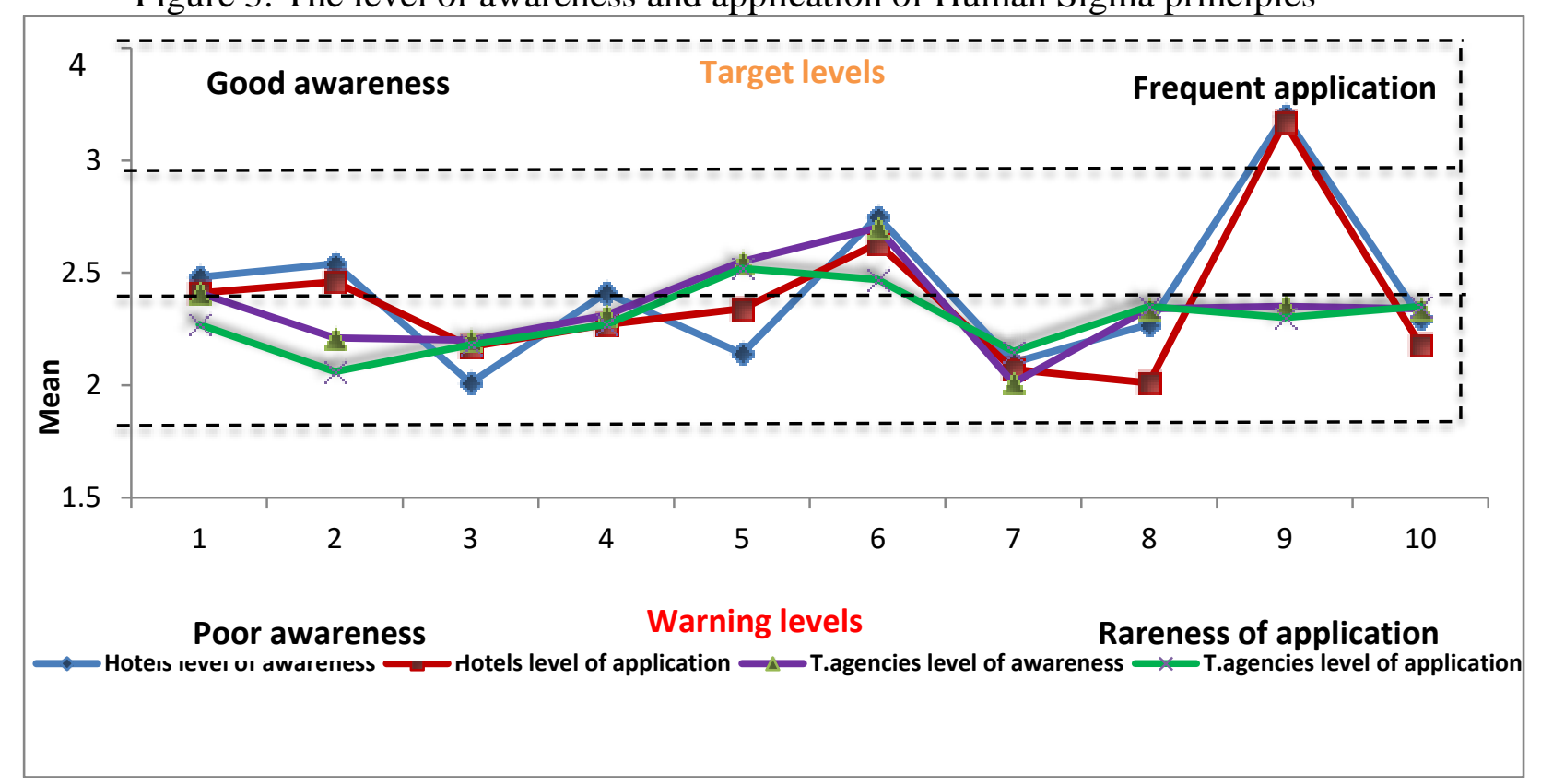

Spearman Correlation Coefficient has been used to determine if there is significant relationship between respondents' characteristics and the levels of awareness and application of business improvement initiatives, including Human Sigma, in the investigated organizations. The results are shown in Table (6).

Table 6: Results of Spearman correlation coefficient test

\begin{tabular}{|l|c|c|c|c|}
\hline Attributes & Type of firm & $\begin{array}{c}\text { Size of the } \\
\text { firm }\end{array}$ & $\begin{array}{c}\text { Duration of } \\
\text { operation }\end{array}$ & $\begin{array}{c}\text { Annual gross } \\
\text { revenue }\end{array}$ \\
\hline Level of awareness & $0.66^{*}$ & $0.43^{*}$ & 0.35 & 0.54 \\
\hline Level of application & $0.53^{*}$ & $0.62^{*}$ & 0.84 & 0.43 \\
\hline
\end{tabular}

$(*)$ The correlation is significant at the $(0.05)$ level.

It could be seen in Table (6) that the computed $\mathrm{r}$ for the significant relationship between type of firm and level of Human Sigma awareness is 0.66 in which it is considered as moderate coefficient because in Pearson Correlation Coefficient, an $\mathrm{r}$ of .8 and above is considered a high coefficient, an $\mathrm{r}$ around .5 is moderate and an $\mathrm{r}$ of .3 and below is considered as low coefficient (James et al., 2013). Therefore, type of firm and level of Human Sigma awareness is significantly related. In addition, the computed $r$ for the significant relationship between type of firm and level of Human Sigma application is 0.53 
which falls on moderate coefficient. Therefore, type of firm and level of Human Sigma application is significantly related. Meanwhile, according to Table (6) the computed $\mathrm{r}$ for the significant relationship between size of the firm and level of Human Sigma awareness is 0.43 in which it is considered as moderate coefficient. Therefore, size of firm and level of Human Sigma awareness is significantly related. Moreover, , the computed $r$ for the significant relationship between size of firm and level of Human Sigma application is 0.62 which falls on moderate coefficient. Therefore, size of firm and level of Human Sigma application is significantly related. According to Table (6), there is no significant effect of the duration of operation and annual gross revenue on levels of Human Sigma awareness and application.

\section{Measurement and management of interactions between customers and employees}

One of the primary objectives of the current study was to estimate the levels of employees and customers engagement in the tourism and hotel industry in Egypt from the perspective of management. This section of the survey was designed to measure the overall efficiency of employee-customer engagement in the investigated organizations. It is worth mentioning that this part of the survey was generated in consistent with prior research developed by Gallup, the worldwide research-based consultancy specializing in employee and customer management. A multiple-item method was adopted and scores are ranked from 1 to 5 , with 1 being not at all in agreement and 5 being extremely in agreement. Results displayed according to the mean values are summarized in Table (7).

Table 7: Criteria of employee-customer engagement

\begin{tabular}{|l|l|l|l|l|}
\hline Variable & \multicolumn{2}{l}{ Hotel Chains } & \multicolumn{2}{l|}{$\begin{array}{l}\text { Travel } \\
\text { Agencies }\end{array}$} \\
\cline { 2 - 5 } & Mean & SD & Mean & SD \\
\hline Employee engagement criteria: & & & & \\
\hline $\begin{array}{l}\text { Employees in my company are willing to accept } \\
\text { organizational changes. }\end{array}$ & 2.63 & 1.03 & 2.55 & 1.14 \\
\hline Employees are willing to take on new tasks as needed. & 2.61 & 1.16 & 2.34 & 0.87 \\
\hline $\begin{array}{l}\text { Employees know exactly what is expected of them at } \\
\text { work. }\end{array}$ & 3.09 & 1.02 & 3.57 & 1.05 \\
\hline $\begin{array}{l}\text { Employees have the materials and equipment needed to } \\
\text { do their work right. }\end{array}$ & 3.58 & 0.99 & 3.40 & 1.02 \\
\hline $\begin{array}{l}\text { Employees are receiving recognition or praise for doing } \\
\text { good work. }\end{array}$ & 3.10 & 1.23 & 2.57 & 0.87 \\
\hline $\begin{array}{l}\text { Employees are receiving personal care from their } \\
\text { supervisors. }\end{array}$ & 3.15 & 1.14 & 2.63 & 0.89 \\
\hline Employees are encouraged to develop themselves. & 3.90 & 0.99 & 2.76 & 0.87 \\
\hline $\begin{array}{l}\text { Employees' voices are considered and counted all the } \\
\text { times. }\end{array}$ & 2.55 & 1.24 & 2.39 & 0.76 \\
\hline Employees are committed to do quality work. & 3.67 & 0.88 & 3.03 & 1.10 \\
\hline $\begin{array}{l}\text { Employees take initiatives to help other employees when } \\
\text { they need arises. }\end{array}$ & 2.85 & 1.13 & 2.34 & 0.99 \\
\hline $\begin{array}{l}\text { Employees proactively identify future challenges and } \\
\text { opportunities. }\end{array}$ & 2.45 & 1.29 & 2.41 & 0.97 \\
\hline $\begin{array}{l}\text { Employees have the opportunities at work to learn and } \\
\text { grow. }\end{array}$ & 3.85 & 0.88 & 3.23 & 0.72 \\
\hline Average employees engagement level & $\mathbf{3 . 1 1}$ & $\mathbf{1 . 0 8}$ & $\mathbf{2 . 7 6}$ & $\mathbf{0 . 9 3}$ \\
\hline
\end{tabular}




\begin{tabular}{|l|l|l|l|l|}
\hline Customer engagement criteria: & & & & \\
\hline $\begin{array}{l}\text { We build strong affinity with our current and former } \\
\text { customers. }\end{array}$ & 3.13 & 1.24 & 2.73 & 1.31 \\
\hline $\begin{array}{l}\text { We improve the relevance and value of communication } \\
\text { with our customers. }\end{array}$ & 3.17 & 1.33 & 2.82 & 1.42 \\
\hline $\begin{array}{l}\text { We develop points of engagement in order to grow } \\
\text { loyalty and advocacy. }\end{array}$ & 3.52 & 1.22 & 3.66 & 1.27 \\
\hline $\begin{array}{l}\text { We gain a deeper understanding of customer needs and } \\
\text { expectations. }\end{array}$ & 3.04 & 1.20 & 3.28 & 1.30 \\
\hline $\begin{array}{l}\text { We develop and sustain customer engagement to achieve } \\
\text { success. }\end{array}$ & 3.66 & 1.22 & 3.39 & 1.29 \\
\hline $\begin{array}{l}\text { We enrich and enliven customer interactions through } \\
\text { digital channels. }\end{array}$ & 3.45 & 1.36 & 2.37 & 1.29 \\
\hline $\begin{array}{l}\text { We provide more personalized, targeted engagements and } \\
\text { experiences. }\end{array}$ & 2.73 & 1.28 & 2.45 & 1.34 \\
\hline $\begin{array}{l}\text { We identify and manage the emotional dimensions of } \\
\text { customer engagement. }\end{array}$ & 2.38 & 1.38 & 2.45 & 1.51 \\
\hline $\begin{array}{l}\text { We create word-of-mouth referral and customer advocacy } \\
\text { programs. }\end{array}$ & 3.04 & 1.22 & 2.88 & 1.41 \\
\hline $\begin{array}{l}\text { We develop new products/services that would be suitable } \\
\text { for our customers. }\end{array}$ & 4.03 & 1.35 & 3.59 & 1.29 \\
\hline We always deliver on what we promise. & 3.82 & 1.33 & 3.68 & 1.27 \\
\hline We always treat our customers fairly. & 3.58 & 1.29 & 3.65 & 1.33 \\
\hline Average customer engagement level & $\mathbf{3 . 2 9}$ & $\mathbf{1 . 2 8}$ & $\mathbf{3 . 0 7}$ & $\mathbf{1 . 3 3}$ \\
\hline
\end{tabular}

Results in Table (7) reveal that the mean values for the criteria of employee engagement in the investigated hotel chains are in the range between 2.45 and 3.90, indicating that the employee engagement criteria, such as employees' willingness to accept organizational changes, considering employees' voices, identifying future challenges and opportunities, taking initiatives, and taking on new tasks as needed, are moderately perceived as engagement criteria for the surveyed hotel chains. At the same time, the mean values for the criteria of customer engagement in the surveyed hotel chains are in the range between 2.38 and 4.03, indicating that the customer engagement criteria, such as identifying and managing the emotional dimensions of customer engagement and providing more personalized, targeted engagements and experiences, are moderately perceived as engagement criteria for the hotel chains sample.

On the other side, the findings in Table (7) reveal that the mean values for the criteria of employee' engagement for travel agencies are in the range between 2.34 and 3.57, indicating that the employee engagement criteria, such as accepting organizational changes, recognition, personal care, training and development, employees' voices, identifying future challenges and opportunities, and taking initiatives, are moderately perceived as engagement criteria for the surveyed travel agencies. At the same time, the mean values for the criteria of customer engagement are in the range between 2.37 and 3.68 , indicating that the customer engagement criteria, such as building strong affinity with current and former customers, improving the relevance and value of communication with customers, enriching and enlivening customer interactions through digital channels, providing more personalized, targeted engagements and experiences, and identifying and managing the emotional dimensions of customer engagement, are moderately perceived engagement criteria for the travel agencies sample. 


\section{Testing equality of means in the two Samples}

As shown in Table (8), a T-test has been used to assess the difference between the two samples with respect to the following criteria: The level of awareness, the level of application, employee engagement, and customer engagement.

Table 8: Testing equality of variable means in the two samples

\begin{tabular}{|l|c|c|}
\hline \multicolumn{1}{|c|}{ Variable } & $\boldsymbol{f}$ & Sig. \\
\hline Level of Awareness & 0.322 & 0.571 \\
\hline Level of Application & 0.071 & 0.0781 \\
\hline Employee engagement criteria & 7.912 & 0.000 \\
\hline Customer engagement criteria & 3.304 & 0.071 \\
\hline
\end{tabular}

The obtained results illustrate that hotels and travel agencies have the same levels of awareness and application of the Human Sigma approach. Moreover, their customer engagement strategies are almost the same. On the other hand, a significant $(\mathrm{p}<0.05)$ difference is only found to be in the employee engagement criteria scores with $f=7.912$. These results may be due to the knowledge and financial ability of hotels compared to travel companies. Thus, hotels can present effective management and quality programs. These programs are usually designed to develop skills and abilities to achieve strategies (Choi and Dickson, 2010).

For further statistical examination of these results, the Human Sigma formula was applied to test the employee-customer engagement levels. Fleming and Asplund (2007) noted that the single score packs the overall adequacy of the employee-customer engagement of any given organization. Consequently, the Human Sigma of an organization is a component of levels of both employee and customer engagement. Therefore, Human Sigma metric is figured out by converting the mean scores of employee and customer engagement into percentile equivalents and then taking the square root of the product of the two percentile values according to the following formula:

$$
\mathrm{HS}=\sqrt{\mathrm{EE} \mathrm{Percentile} \mathrm{x} \mathrm{CE} \mathrm{Percentile}}
$$

Consequently, for the five-star hotel chains, the Human Sigma score equals SQRT $(62.2 \mathrm{x}$ $65.8)=$ SQRT $(4092.7)=31.98$. According to the Human Sigma formula, this score will be located in Human Sigma 3 as Human Sigma $1=0$ to less than 10; Human Sigma $2=10$ to less than 30; and Human Sigma $3=30$ less than 50 (Fleming and Asplund, 2007). Since 31.98 is less than 50, it is located in Human Sigma 3 (Average customer engagement and average employee engagement). This means that five-star hotel chains in Egypt are frequently out of balance, positioning high on one indispensable sign yet poor on the other. However, the Human Sigma score for travel agencies equals SQRT (55.2 x 61.4) = SQRT $(3389.28)=29.10$. Since this score is less than 30, it is located in Human Sigma 2 (Average customer engagement and poor employee engagement). This means that travel agencies in Egypt perform essentially less than impressive on employee or customer engagement metrics, and they require critical mediation and improvement.

\section{Obstacles affecting the formal engagement measurement program implementation}

The respondents have been asked to indicate the reasons that hinder the business implementing any formal employee-customer engagement measurement programs. The most common reasons reported are shown in Figure (4). Results indicate that lack of clear knowledge and satisfaction with the existing improvement programs are both considered the main obstacles that hotels encounter when applying a formal engagement measurement 
program in their premises. Meanwhile, complexity of the Human Sigma principles, lack of financial funding, more paperwork, and lack of customer focus followed respectively the main obstacles. Furthermore, in travel agencies, results indicate that lack of clear knowledge and complexity of the Human Sigma principles are considered the main barriers that travel agencies encounter when applying a formal engagement measurement program in their premises. Satisfaction with the existing improvement programs, Lack of financial funding, more paperwork, lack of customer focus and Lack of financial funding followed respectively the main obstacles.

Figure 4: Obstacles affecting the implementation of engagement measurement program

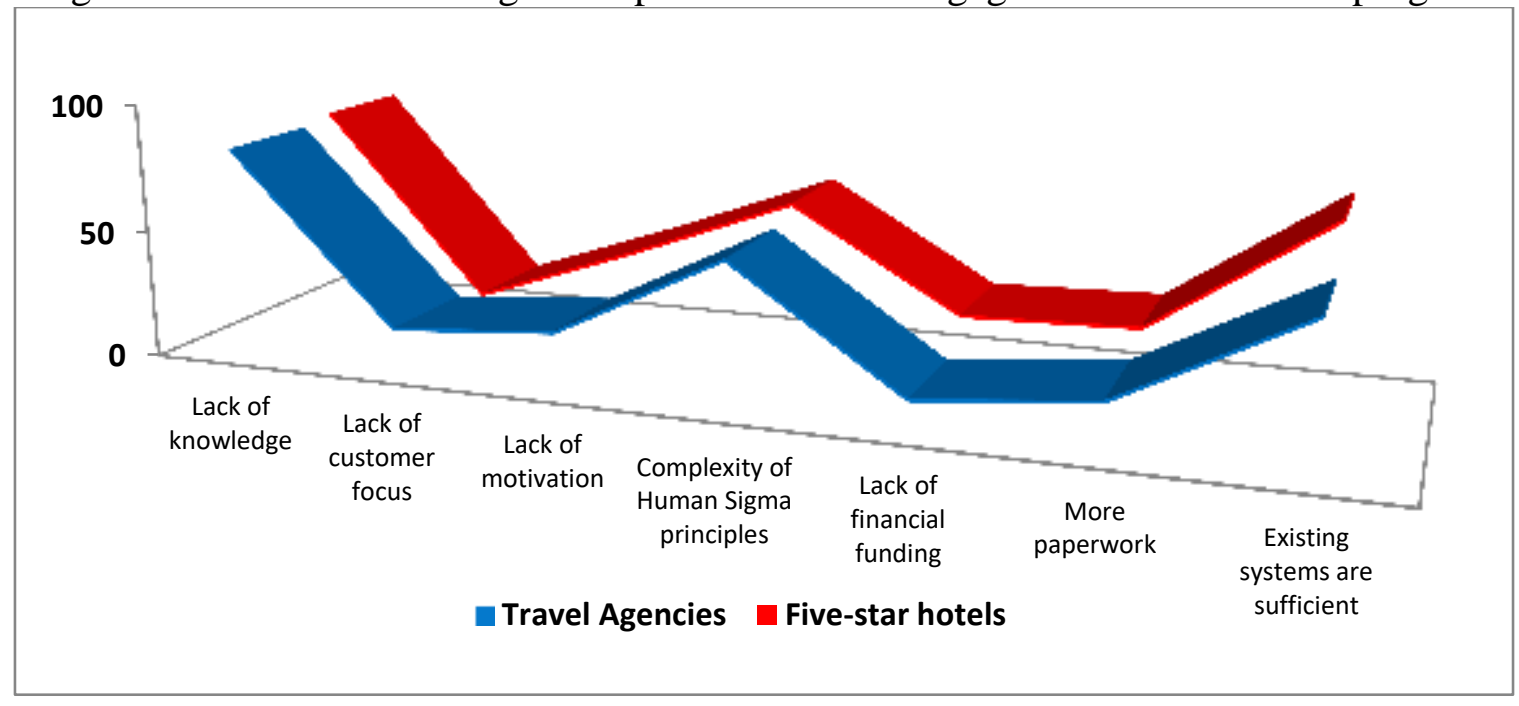

\section{Discussion and proposed framework}

The current study is the first known examination of the levels of knowledge, understanding, and implementation of the Human Sigma concept in the tourism and hotel industry in Egypt. With such an imperative place in the Egyptian economy, it is very important for this industry to implement continuous improvement techniques to properly measure and manage employee-customer engagement. Therefore, a questionnaire survey has been carried out with the aim to identify whether tourism and hotel organizations in Egypt have formal employee-customer engagement measurement programs in place and to identify the managerial perspectives regarding the measurement and management of interactions between customers and employees. Based on the statistical analysis of the survey responses, important findings are revealed.

When compared to other business improvement initiatives, customer satisfaction is perceived as the most implemented quality initiative in both five-star hotel chains and travel agencies, while culture change programs are found to be the least implemented. Managers in tourism and hospitality should be responsible for guest satisfaction. However, they often have little guidance on the best way to figure out whether they have conveyed a satisfactory service experience (Hudson et al., 2004). Overall, it can be concluded that five-star hotel chains have a significantly higher mean score than travel agencies in implementing quality initiatives. Moreover, the findings have shown that five-star hotel chains are more committed to quality management and are significantly higher in gaining quality certificates than travel agencies. Every participant in the quality assessment scheme is normally evaluated on three levels: minimum requirement, available facilities and services, and quality scores. Grading schemes and other quality certifications are critical ways for influencing the levels of overall performance of any given organization (Dale, 2003). These grading and quality certifications indicate how tourism and hotel 
organizations are performing against a range of standards and schemes (Williams and Buswell, 2003). These results are not surprising since this category of hotels corresponds to firms with more possibilities to apply a quality management system and obtain quality certifications.

A marginal proportion of the respondents were actively involved in the application of formal employee-customer engagement measurement program (Human Sigma); however a significant proportion of the respondents recognized Human Sigma. Thus, it can be inferred that Human Sigma has not been grasped by the tourism and hotel organizations in Egypt. These results clearly reveal the alarming situation regarding the applicability of formal employee-customer engagement measurement program in the tourism and hotel organizations in Egypt. It is clearly shown that the general propensity of five-star hotel chains and travel agencies investigated in this study is characterized by low application rates. It is recognized by Kumar et al. (2009) that the poor application of quality management activities such as Six-Sigma is because of numerous and complex reasons, not only the regularly expressed hindrances of cost, time and relative effects. It is obvious from the results that Human Sigma principles seem to be complicated and difficult to interpret by tourism and hotel organizations in Egypt, which might be a significant reason to its rare application. The low levels of application of the Human Sigma principles in the investigated firms are expected to have negative impact on the employee-customer engagement levels of the entire industry in Egypt. Also, it can be inferred that tourism and hotel organizations in Egypt are not attempting to engage their employees and customers to deeper levels. This actually brings up the issue as to whether it is conceivable to apply a formal employee-customer engagement measurement program in the tourism and hotel organizations in Egypt and the difficulties they confront in doing as such.

It is the researchers' point of view that it would be troublesome for tourism and hotel organizations in Egypt to make progress in business execution through the quality initiatives only without enhancing and improving employee-customer engagement through deliberate application of the Human Sigma principles. By effectively implementing Human Sigma, it is expected that there would be an improvements in customer satisfaction, reflecting the better management and control being applied to employeecustomer encounter in Egyptian tourism and hotel sectors. Firms could then be expected to begin to move toward improving service quality practices, which should contribute to giving these organizations a greater competitive advantage in local, national, and global markets.

Suggestions that organizations characteristics and classification may act as intervening variables in empirical tests regarding Human Sigma awareness and application are supported by the results presented in this study. The type of firm and level of Human Sigma awareness and application were significantly related. Moreover, the size of firm and level of Human Sigma awareness and application were significantly related. According to this study, there is no significant effect of the duration of operation and annual gross revenue on levels of Human Sigma awareness and application. These findings may be explained in part by the arguments that incentives for Human Sigma adoption differ depending on firm size. Firm size directly affects the ability of a firm to undergo through formal system to measure and mage employee-customer engagement levels. Large companies have not only the required financial resources, but also the skilled workforce and the competent management able to document the approach, carry out changes and audit the new processes (Tsekouras et al., 2002). As a result, it is not surprising to find out that larger firms are more likely to adopt formal employee-customer engagement measurement programs. Additional work is needed to improve understanding of the 
empirical associations between organizations characteristics and levels of human Sigma adoption.

The Human Sigma formula has been applied to test the employee-customer engagement levels. The questionnaire survey is adapted to measure organizational identification and social identification as a key determinant for managing and measuring the employeecustomer encounter. Therefore, this study has given a substantial and dependable instrument that considers the nature of the service experience. Specifically, the new scale can recognize the diverse sorts of distinguishing proof (organization, employee, and customer); and, in this way, it provides the details necessary to evaluate the qualities and shortcomings of the employee-customer encounter. This study has exhibited how the Human Sigma model can fill in as a tool to gauge and manage the employee-customer encounter. From this perspective, this study has reached the conclusion that there should be a noteworthy move far from exclusively concentrating on the employee-customer encounter organizational identification toward an expanded understanding of different variables that can shape the premise of the measurement and management of the service encounter. The Human Sigma score for five-star hotel chains in Egypt are frequently out of balance, positioning high on one indispensable sign, yet poor on the other. On the other hand, the Human Sigma score for travel agencies is less than impressive with regard to employee or customer engagement metrics. It also requires critical mediation and improvement.

Results indicate that the lack of clear knowledge and satisfaction with the existing improvement programs are both considered the main obstacles that hotels encounter when applying formal engagement measurement programs. Meanwhile, complexity of the Human Sigma principles, Satisfaction with the existing improvement programs, Lack of financial funding, more paperwork followed respectively the main obstacles. On the other side, in travel agencies, results indicate that the lack of clear knowledge and complexity of the Human Sigma principles are considered the main barriers travel agencies encounter when applying formal engagement measurement programs in their premises. Lack of financial funding, more paperwork, and lack of customer focus followed respectively the main obstacles. These findings are in line with the ones cited in previous Human Sigma literature (Fleming and Asplund2007; Choi and Dickson, 2010; Sutton, 2014a; Sutton, 2015). Based on the review of the related literature and the analysis of the study findings, a proposed framework for effective Human Sigma implementation is being suggested, as shown in Figure (6).

Figure 6: A Proposed framework for effective Human Sigma implementation

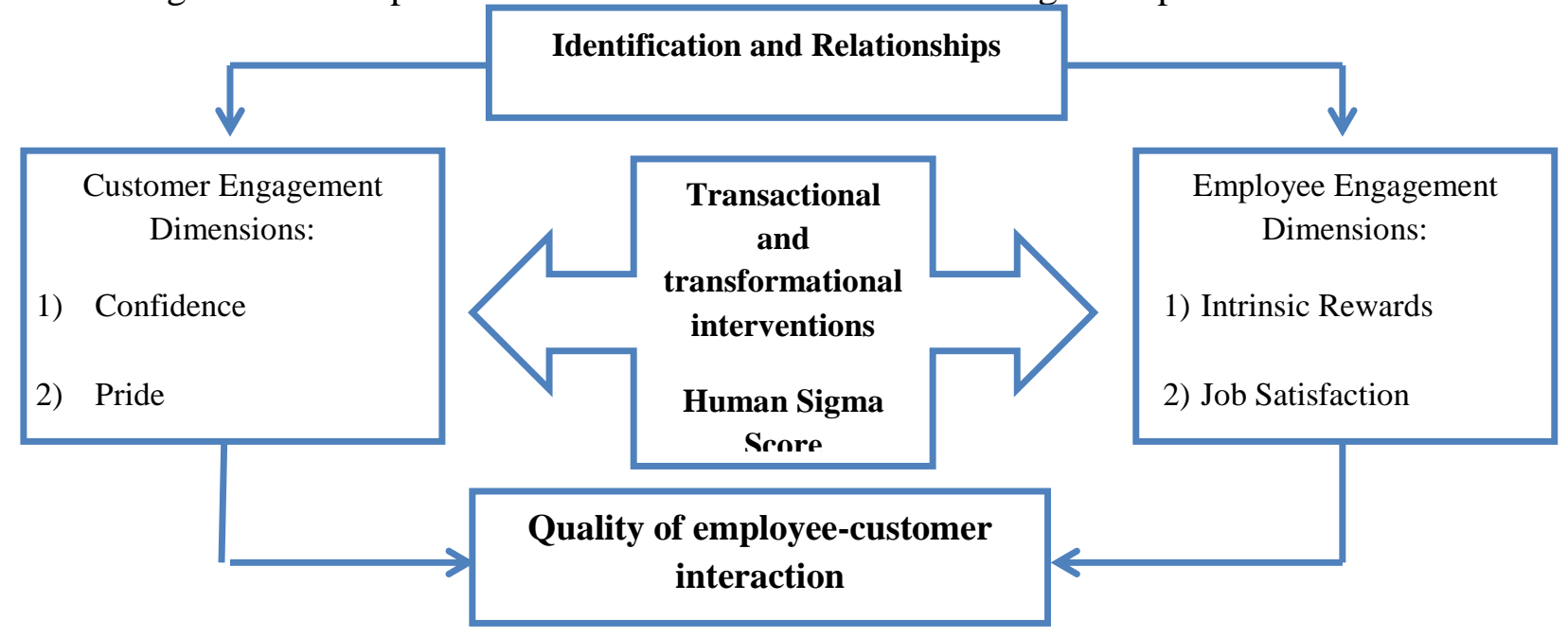




\section{Limitations and directions for future research}

The current study concentrates on five-star chain hotels in Egypt .Other Egyptian lodging appraisals are not considered. It is also valuable to choose other types of firms such as airlines in order to have a more comprehensive view. Furthermore, it would be useful to examine feedback of the tourism and hotel organizations who have achieved success in using the Human sigma approach as technique for quality management. Moreover, a deeper examination of the benefits and the critical success factors for implementing the Human Sigma approach in the tourism and hospitality industry should be a primary focus of further research.

\section{References}

Adams, C., Gupta, P. and Wilson, C. (2003): Six-Sigma Deployment, Butterworth Heinemann, Burlington, MA.

Aichouni, A., Messaoudene, N., Al-Ghonamy, and Touahmia, M. (2014): An empirical study of quality management systems in the Saudi construction industry. International Journal of Construction Management, 14(3):181-190.

Antony, J. (2005): Six-Sigma for Service Processes, Business Process Management Journal, 12(2): 234-248.

Antony, J., Antony, F. J and Kumar, M. (2007): Six-Sigma in service organizations, International Journal of Quality \& Reliability Management, 24(3): 294-311.

Bakker, A., Albrecht, S. and Leiter, M. (2011): Key questions regarding work engagement, European Journal of Work and Organizational Psychology, 20, 4-28

Barnes, D., Collier, J., and Robinson, S. (2014): Customer delight and work engagement, Journal of Services Marketing, 28(5): 380-390.

Bassi, L. and McMurrer, D. (2007): Maximizing your return on people. Harvard Business Review, 85(3): 115-123.

Baurn, T. (2007): Human resources in tourism: Still waiting for change, Journal of Tourism Management 28: 1383-1399.

Bekhet, H. and Al-Alak, B. (2011): Measuring factors affecting the adoption of estatement in Malaysia, $5^{\text {th }}$ International conference on Services Management, Gurgaon, India.

Boulding, W., Kalra, A., Staelin, R. and Zeithaml, V. (1993): A dynamic process model of service quality: from expectations to behavioral intentions, Journal of marketing research, 30(1), 7-27.

Bowden, J. (2009): The process of customer engagement: A conceptual framework. Journal of Marketing Theory and Practice, 17(1): 63-74.

Bramulya, R. (2016): Impact of relationship marketing, service quality and customer orientation of service employees on customer satisfaction and behavioral intention and its impact on customer retention, International Journal of Economics, Commerce and Management, 5:151-16

Brodie, R., Ilic, A., Juric, B. and Hollebeek, L. (2013): Customer engagement in a virtual brand community: An exploratory analysis, Journal of Business Research, 66: 105114.

Choi, Y. and Dickson, D. (2010): A case study into the benefits of management training programs: Impacts on hotel employee turnover and satisfaction level, Journal of Human Resources in Hospitality and Tourism, 9(1): 103-116.

Coffman, C. and Michelman, P. (2004): Break all the rules: Managing employee and customer engagement to drive profitable performance, Harvard Business School Publishing Conferences, available at: http://conferences.harvardbusinessonline.org (accessed 12/3/2016) . 
Coulter, K.S. and Coulter, R.A. (2002): Determinants of Trust in a Service Provider: The Moderating Role of Length of Relationship, Journal of Services Marketing, 16(1): 35-50

Crick, A. P. and Spencer, A. (2001): Hospitality quality: New directions and new challenges, International Journal of Contemporary Hospitality Management, 23(4), pp. 463-478.

Cronin, J. and Taylor, S. (1992): Measuring service quality: A re-examination and extension, Journal of Marketing, 56(7):55-68.

Dale, B. and McQuater, R. (1998): Managing business improvement and quality: Implementing key tools and techniques, Blackwell Business Publishers, Oxford.

Dale, B.G. (2003): Managing quality, $4^{\text {th }}$ ed., Blackwell Publishing, Oxford.

Egypt State Information Service (ESIS) (2016): Introduction. Available at: http://www.sis.gov.eg, (accessed 20/ 5/ 2016).

Devie, A., Tarigan, J. and Widjaja, D. (2001): The impact of employee satisfaction on profitability of restaurants and cafés: A research in Surabaya, Indonesia International Conference on E-business, Management and Economics.25:266-270.

Eldor, L. and Vigoda-Gadot, E. (2016): The nature of employee engagement: rethinking the employee-organization relationship, The International Journal of Human Resource Management, (Online) available at : http://pmpc.haifa.ac.il/images/Eran_Academic_Profile/Download_Major_Publicati ons/C._Articles_in_refered_journals/IJHRM-2016.pdf(Accessed 12/4/2016)

Fernandes, T. and Esteves, F. (2016): Customer engagement and loyalty: A comparative study between service contexts, Services Marketing Quarterly, 37(2):125-139.

Fitzsimmons, J.A. and Fitzsimmons, M. (2002): New service development creating memorable experiences, Sage Publications, Thousand Oaks, CA.

Fleming, J.H., Coffman, C. and Harter, J. (2005): Manage your Human Sigma. Harvard Business Review, July-August, 106-114.

Fleming, J. and Asplund, J. (2007): Human Sigma: Managing the employee-Customer Encounter. Gallup Press, New York, USA: 10.

Ford, R., Stuman, M., and Heaton, C. (2012): Managing quality service in hospitality: How organizations achieve excellence in the guest experience, Delmar, Cengage Learning: 13.

Gemmel, P. and Verleye, K. (2010): Emotional attachment to a hospital: Bringing employees and customers into the engagement zone, Journal of Applied Management of Entrepreneurship, July, 15(3):78-93.

Gupta, S. and Zeithaml, V. (2006): Customer metrics and their impacts of financial performance, Marketing Science, 25(6): 718-739.

Hansson, J. and Klefsjö, B. (2003): A core value model for implementing total quality management in small organizations, The TQM Magazine, 15(2): 71-81.

Hudson, S., Hudson, P. and Miller, G. (2004): The measurement of service quality in the tour operating sector: a methodological comparison, Journal of Travel Research, 42(1): 305-312.

Jamal, A. \& Adelowore, A. (2008): Customer-employee relationship: The role of selfemployee congruence, European Journal of Marketing, 42(11/12): 1316-1345.

James, G., Witten, D., Hastie, T. and Tibshirani, R. (2013): An introduction to statistical Learning with applications in R, Springer Science and Business Media, New York.

Kandampully, J. (2003): Services management: The new paradigm in hospitality. Prentice Hall, New Jersey.

Kandampully, J., Mok, C. and Sparks, B. (2001): Service quality management in hospitality, Tourism, and Leisure. The Haworth Press, New York. 
Kelemen, M. (2006): Managing quality: managerial and critical perspectives, Sage Publications, London.

Khan, M. (2003): ECOSERV: Ecotourists' quality expectations. Annals of tourism research, 30(1): 109-124.

Kumar, M., Antony, J. and Douglas, A. (2009): Does size matter for Six-Sigma implementation, The TQM Journal, 21(6): 623-635.

Kumar, M. and Antony, J. (2008): Comparing the Quality Management Practices in UK SMEs', Industrial Management and Data Systems, 108(9):1153-1166.

Lev, B. (2001): Intangibles: Management, measurement, and reporting. Brookings Institution Press.

Lovelock, C. and Wirtz, J. (2011): Service marketing: people, technology, strategy. Pearson, Prentice-Hall, New Jersey.

Maslach, C., Schaufeli, W. and Leiter, M. (2001): Job Burnout, Annual Review of Psychology, 52: 397-422.

Mercy,O.and Taiye,B. (2015): Strategic Imperatives of Total Quality Management and Customer Satisfaction in Organizational Sustainability, International Journal of Academic Research in Business and Social Sciences, 5(4):1-22.

Michelli, J. A. (2008): The new gold standards. The McGraw-Hill, New York.

Montasser and Al Manhawy, A. (2013): TQM critical success factors in hospitality Industry and their impact on Customer Loyalty, a theoretical Model International Journal of Scientific \& Engineering Research, 4(1), 1-15

Nield, K. and Kozak, M. (1999): Quality certification in the hospitality industry: Analyzing the benefits of ISO 9000, Cornell Hotel and Restaurant Administration Quarterly, 40(2), 40-45.

Niven, P. (2005): Balanced scorecard diagnostics: Maintaining maximum performance, Wiley, New Jersey.

Nulty, D. (2008): The adequacy of response rates to online and paper surveys: what can be done, The Assessment \& Evaluation in Higher Education, 33(3), June, 301-314

Pabedinskait, A. and Vitkauskas, R. (2011): Quality management tools: Analysis of Lithuanian enterprises, $6^{\text {th }}$ International Scientific Conference, May 13-14, 2010, Vilnius, Lithuania.

Patterson P., Yu T., and de Ruyter, K. (2006): Understanding customer engagement in services, Advancing theory, maintaining relevance, proceedings of ANZMAC 2006 conference, Brisbane, 4-6 December.

Pirnar I., Icoz, O. and Icoz, O. (2010): The new tourist: Impacts on the hotel marketing strategies, EuroCHRIE Amsterdam 2010, Passion for Hotel Excellence, 25-28 October.

Puriwat, W. and Tripopsakul, S. (2014): The Investigation of the influence of service quality toward customer engagement in service dominant industries in Thailand, $3^{\text {rd }}$ International Conference on Business, Management and Governance: 42-49.

Raghunath A. and .Jayathirtha R .V. (2013): Barriers for implementation of Six Sigma by Small and Medium Enterprises. International Journal of Advancements in Research \& Technology, 2 (2):1-7.

Rath, T. (2004): The impact of positive leadership: How seemingly small interactions can dramatically boost your team's productivity, Gallup Management Journal, available http://www.gmj.gallup.com (accessed 22/ 1 /2016).

Rich, B., Lepine, J., and Crawford, E. (2010): Job engagement: Antecedents and effects on job performance, Academy of Management Journal, 53: 617-635. 
Rothbard, N. (2001): Enriching or depleting: The dynamics of engagement in work and family roles, Administrative Science Quarterly, 46: 655-684.

Rothbard, N., and Patil, S. (2010): Being there: Work engagement and positive organizational scholarship, the Oxford handbook of positive organizational scholarship. Oxford: Oxford University Press: 59-69.

Schroder, L. (2002): Improve the effectiveness of teller training, Teller Vision, 856(S):7.

Slåtten, T., and Mehmetoglu, M. (2011): Antecedents and effects of engaged front line employees: a study from the hotel industry, Management Service Quality, 21 (1): 88-107.

Solnet, D. (2006): Introducing social identification to customer satisfaction research, Managing Service Quality, 16 (62): 575-594.

Sluss, D. and Ashforth, B. (2007): Relational identity and identification: Defining ourselves through work relationships', Academy of Management Review, 32(1): 932.

Simon, D. and Gomez, M. (2005): The competitive causes and consequences of customer satisfaction paper prepared for presentation at the American agricultural economics association annual meeting, Providence, Rhode Island, Available at: http://ageconsearch.umn.edu ( accessed 22/ 4 /2016).

Sutton, C. (2014 a): The applicability of the Human Sigma model to service quality management in the UK tourism industry: An operational analysis, Ph.D. Thesis, the University of Central Lancashire.

Sutton, C. (2014b): Adapting the human sigma instrument to enhance the Employee-Customer Encounter, The Journal of Applied Management and Entrepreneurship, 19 (3).

Sutton, C. (2015): The human sigma approach to business improvement in tourism SMEs, Journal of Small Business and Enterprise Development, (22): 2 -23.

Torres, E. and Kline, S. (2006): From satisfaction to delight: A model for the hotel industry. International Journal of Contemporary Hotel Management, 18(4): 290301.

Tsekouras, K., Dimara, E., and Skuras, D. (2002): Adoption of a quality assurance scheme and its effect on firm performance: A study of Greek firms implementing ISO 9000, Total Quality Management, 13(6), 827-841.

Tyler, K. (2005): Training revs up: Companies are realizing that enhanced performance requires a bigger training engine. HR Magazine, 50(4): 58-63.

Udayai K., and Kumar P. (2012): Implementing Six-Sigma to improve hospital discharge process, International Journal of Pharmaceutical Sciences and Research, 3(11).

United Nations Environment Program (UNEP) and World Tourism Organization (WTO) (2005) Making tourism more sustainable: A guide for policy makers, available at: http://www.unep.fr/shared/publications, (accessed 23 /4/ 2016).

Wagner, R. and Harter, J. (2006): The elements of great managing, NY, Gallup Press, New York.

Wang, M., Liao, H., Zhan, Y. and Shi, J. (2011): Daily customer mistreatment and employee sabotage against customers: examining emotion and resource perspectives. Academy of Management Journal, 54(2):312-334.

Welch, J. and Welch, S. (2006): Ideas the Welch way: how healthy is your company? New York, Businessweek, 126.

Williams, C. and Buswell, J. (2003): Service quality in leisure and tourism, CABI Publishing, Wallingford. 
Vivek SD, Beatty SE, Morgan RM. (2012): Consumer engagement: Exploring customer relationships beyond purchase, Marketing Theory and Practice, forthcoming, London.

Yarimoglu, E. (2014): A Review on dimensions of service quality models, Journal of Marketing Management, 2(2), 79-93.

Yee, R., Yeung, A. and Cheng, T. (2008): The Impact of Employee Satisfaction on Quality and Profitability in High-contact Service Industries, Journal of operation management 26 (5):651-668.

Zairi, M. (2002): Total quality management sustainability, International Journal of Quality and Reliability Management, 19(5), 491-540.

Zweifel, H. (2010): Human Sigma Optimization: Engaging Employees and Customers, Dissertation, University of St. Thomas. 